\title{
TAKING THE OMBUDSMAN CONCEPT INTO THE PRIVATE SECTOR: NOTES ON THE BANKING OMBUDSMAN SCHEME IN NEW ZEALAND
}

Nadja Tollemache OBE*

This paper traces the development of the institution of Ombudsman in New Zealand and comments on the move of the idea from the public to the private sector. In the private sector, developments in New Zealand followed other common law countries. New Zealand appointed its first Banking Ombudsman in July 1992.

New Zealanders pride themselves on some notable examples of social legislation which have taken the New Zealand legal system to the forefront of progress; for example, the granting in 1893 of the suffrage to women, and some innovative family property legislation in the early part of this century. Another such piece of legislation and one that has greatly influenced the whole range of public administration in New Zealand is the Ombudsman Act 1962, which made New Zealand the first English -speaking, common law, commonwealth country in the world to adopt a dispute resolution system that originated in Sweden.

The basic idea behind the system is that the individual, who is in a David and Goliath situation when taking on the immeasurably more powerful public authorities, should be able to turn to an impartial person who can look at complaints about matters of administration, can access all the facts, including departmental files and memoranda, and can decide whether the decision or other act complained of was deficient according to a list of statutory criteria now set out in section 22 of the Ombudsmen Act 1975. ${ }^{1}$ Not only actions and decisions, but also that most difficult form of maladministration, inaction and delay, are covered.

* Parliamentary Ombudsman 1987-1992; first New Zealand Banking Ombudsman 1992-1995.

1 Parliamentary Commissioner(Ombudsman) Act 1962, now consolidated and amended in the Ombudsmen Act 1975. 
The first test under section 22 is that the act which is the subject matter of the investigation "appears to have been contrary to law". ${ }^{2}$ The drafting here is significant; an Ombudsman does not make pronouncements on the law- that is the function of the courtsbut he or she forms an opinion that something "appears" to be contrary to law. Quite often, in my experience during my term of office from 1987 to 1992, the unlawfulness consisted of charging a member of the public for services which the department or other organisation was legally obliged to provide, without any authority to make such a charge. The newly formed bodies such as state owned enterprises, but also restructured departments, had to be reminded firmly of the constitutional principles that applied to them as much as to any other public body, and that the new general philosophy of "user pays" did not provide them with statutory authority to make specific charges. ${ }^{3}$

The test of lawfulness is, then, the first of the criteria. Another is whether the action was: ${ }^{4}$

unreasonable, unjust, oppressive or improperly discriminatory or (and this was the innovative part) was in accordance with a rule of law or a provision of any Act, regulation, or bylaw or a practice that is or may be unreasonable, unjust, oppressive or improperly discriminatory.

It must be remembered that when the Ombudsman Act was passed in 1962, the great development of administrative law through the courts was yet to come; the term "unreasonable" has not been interpreted as incorporating any jurisdictional "Wednesbury" subtleties. ${ }^{5}$ It meant, and for the Ombudsman's office continued to mean, what ordinary people would think unacceptable. And "discrimination", which has become the focus for much discussion since the passing of the race relations and human rights legislation, ${ }^{6}$ was

2 Ombudsmen Act 1975, s 22(1)(a).

3 See the Report of the Ombudsmen for the year ended 30 June 1992, page 42.

4 Above n 2, s 22(1)(b).

5 Associated Provincial Picture Houses Ltd $v$ Wednesbury Corporation [1948] 1KB 223 (CA); action for a declaration that a condition imposed by the local authority was ultra vires and unreasonable. Lord Greene MR pointed out that a discretion must be exercised reasonably and gave examples of various meanings of "unreasonable". Of the argument of counsel for the Associated Picture Houses, Lord Greene commented "he is really saying that the ultimate arbiter of what is and is not reasonable is the court and not the local authority..... and in the end he agreed that his proposition.......really meant that it must be proved to be unreasonable in the sense that the court considers it to be a decision that no reasonable body could have come to". He continued "the effect of the legislation is not to set up the court as an arbiter of the correctness of one view over another ... provided they act, as they have acted,within the four corners of their jurisdiction , this court, in my opinion, cannot interfere". The Ombudsman's role is very different and is not confined to jurisdictional unreasonableness but can examine the merits.

6 Race Relations Act 1971, Human Rights Commission Act 1977, New Zealand Bill of Rights Act 1990, Human Rights Act 1993. 
then also uncharted territory. It was a bold step to empower the Ombudsman to not only test acts of the administration against these criteria, but also to scrutinise the law and practice on which the acts were based. If the law or practice were found wanting, sections 22(3)(d) and (e) specifically empowered the Ombudsman to recommend reconsideration of such law or practice, and the Ombudsmen have not been slow over the years to carry out that mandate. It is, however, clearly an area where diplomacy and common sense are required since a recommendation impugning the reasonableness of a recently passed and properly considered piece of legislation would not only not be accepted, but would be counterproductive. In areas where the Ombudsmen have particular experience or expertise, ${ }^{7}$ it would therefore be wiser to point out problems in proposed legislation before it became law. ${ }^{8}$

Of the other tests under section 22 , the test "whether the action was based wholly or partly on a mistake of law or fact"9 seems less remarkable now that the Contractual Mistakes Act 1977 and the Contractual Remedies Act 1979 have accustomed us to remedies for mistake in areas covered by that legislation. But operative mistake even in contracts was very limited in 1962 . Yet many administrative decisions, both then and now, especially in the social welfare area, can be made on a mistaken basis and can be particularly traumatic for someone whose benefit is stopped or cut back; even if the mistake is later rectified, the effect of a mistaken benefit cancellation can be disproportionately harsh.

The final criterion under section 22, "that the action was wrong"10 is extraordinarily wide, but there have been few situations where an Ombudsman has had to base a recommendation exclusively on that ground, and naturally the greatest care is taken to support the opinion in such a way that any recommendation based on it is sufficiently persuasive to be accepted.

There is one other basis for action in section 22 which, with the development of administrative law by the courts and the coverage by later legislation, ${ }^{11}$ has become

7 This was particularly true of matters relating to the Official Information Act 1983 after the demise under the "sunset clause" (section 53) of the Information Authority, which had been charged with, inter alia, reviewing legislative protection of official information and with recommending changes to make information more accessible and to prevent improper use of personal information; Official Information Act1982, ss 38 and 39.

8 See Reports of the Ombudsmen for the years ending 30 June 1992 (at pages 16 and 49); 1993 (at pages 15, 49) 1994(at page 43).

9 Above n 2, s.22(1)(c).

10 Above n 2, s 22(1)(d).

11 Of particular importance has been the right to reasons for decisions under $\mathrm{s} 23$ of the Official Information Act 1982 and s 22 of the Official Information and Meetings Act 1987. 
perhaps less vital but still provides an enormously important statement about administrative standards. It is that: ${ }^{12}$

in the making of the decision or recommendation, or in the doing or omission of the act, a discretionary power has been exercised for an improper purpose or on irrelevant grounds or on the taking into account of irrelevant considerations, or that...reasons should have been given for the decision.

I believe there is nothing that concentrates the mind of an official more wonderfully than to have to give reasons for a decision.

While much more could be said about the basis for action on which Ombudsmen carry out their functions, the statutory criteria in section 22 have been picked out because they sum up the aim of the whole exercise: to achieve fairness in administration.

Since 1962 the Ombudsman system of complaints resolution has spread world-wide, and many countries have taken note in setting up their own schemes of the New Zealand legislation and experience. While there are variants to suit conditions in different countries, there are some typical characteristics. Access to the Ombudsman is usually direct, informal and free of charge. The Ombudsman's procedures are non-adversary and non-technical and reasons are given for whatever is decided. ${ }^{13}$ Recourse to the Ombudsman is only after the respondent department or other organisation has been given the chance to put its own house in order; in other words, it is a last resort after internal complaints procedures and appeals have failed to provide a resolution. ${ }^{14}$ If the Ombudsman does find after investigation that there has been some maladministration, there is usually a wide range of possible recommendations that would put matters to rights. ${ }^{15}$

The success of Ombudsmen schemes in the public sector in a wide range of countries, and particularly their cost-effectiveness as a dispute resolution mechanism, has been such that it is not surprising that the system has been transferred to the private sector; the issue this brief paper seeks to raise for consideration is whether the concept of "fairness" has suffered a sea-change in being transmuted from the public to the private sector. But first, some background on the transfer of the Ombudsman idea to the private sector must be sketched in.

In this matter New Zealand cannot claim to have led the way. The first private sector Ombudsman in New Zealand, the Banking Ombudsman, is an office that came into operation

12 Above n 2, s 22(2).

13 Above n 2, ss21 and 22(3)(g).

14 Above n 2, ss13(7)(a) and 17 (1)(a).

15 Above n 2, s 22(3). 
on 1 July 1992 and was closely modelled on similar offices in the United Kingdom and Australia.

In the United Kingdom the starting point for use of a private sector Ombudsman was unquestionably the creation in 1981 of the Insurance Ombudsman Bureau. It was the success of a self regulatory but independent Ombudsman in the insurance industry that gave the impetus for other commercial sector Ombudsman schemes for banks, building societies, investment advisors falling under the FIMBRA and IMRO umbrella, and pensions.

The United Kingdom Banking Ombudsman became operational in 1986 and there is little doubt there was an element of a defensive pre-emptive strike in the setting up of the office: after the 1986 Financial Services Act the banks were faced with the option of either reforming their own grievance resolution procedures for customers or the unpalatable possibility of an imposed, tough, statutory regime. ${ }^{16}$ Similarly in Australia, where relationships between banks and customers had fallen to a low ebb, the proposal for an independent dispute resolution mechanism intermediate between the institutions and the courts was endorsed by the Treasury and the Trade Practices Commission. ${ }^{17}$

In New Zealand the setting up of the Banking Ombudsman scheme proceeded along a slightly different path. The first difference was a matter of sequence of events; in New Zealand the Code of Banking Practice came into operation before any Ombudsman was appointed, ${ }^{18}$ which had a number of effects. First, the Code itself made membership of the Ombudsman scheme obligatory to those banks that adhered to the Code, ${ }^{19}$ and there was therefore no "opting in" after the scheme had commenced as there was in the UK and in Australia; as a result all the participating banks could be brought in by the Banking Ombudsman to co-operate in discussions on the best procedures to put in place. Under the Code, the banks were also obliged to put in place internal complaints procedures. Secondly, since the Code was already in place, the first Banking Ombudsman was not involved in the process of drafting it, which elsewhere has given rise to considerable debate and which, in Australia, involved the Ombudsman in a somewhat tense and controversial role. Thirdly, in the Code the banks set out the minimum standards of good banking practice; if these were breached there was therefore no room for argument if the Banking Ombudsman found a

16 The Jack Committee suggested that the industry sponsored scheme be supplanted by a statutory one; Banking Services: Law and Practice Report by the Review Committee Professor RB Jack (Chairman) HMSO Cm 622.

17 Electronic Funds Transfer: Report by the Treasury and Trade Practices Commission on dispute resolution, July 1989.

18 The Code came into effect on 1 March 1992, having been published in January.

19 The Code in Clause 1.1 set out standards to be observed by Member banks of the New Zealand Bankers' Association; in Clause 21.3 Banks subscribing to the Code were to belong to the Banking Ombudsman scheme and to have publicly available in all branches details of the scheme. 
complainant's case had been made out, and indeed a majority of early complaints did not need to be fully investigated since the outcome was clearly predictable and, on reference to the banks own internal procedures, could be satisfactorily resolved.

The second difference was a matter of structure. Whereas in the United Kingdom and Australia a tripartite, corporate form for the scheme was chosen, in New Zealand a simpler, unincorporated form was chosen consisting of the Commission and the Ombudsman's office.

The important thing is that whether a corporate form is chosen or not, it is essential that there should be a manifestly independent body interposed between the funding member banks (who will be the "respondents" in any investigations) and the Ombudsman. In New Zealand this body is the Banking Ombudsman Commission, chaired by a retired Court of Appeal judge, with two consumer and two banking representatives. It is the Commission's function to appoint the Banking Ombudsman, to collaborate with Government or any corporations on matters affecting banking, to consider and approve the budget, to levy, charge and collect the necessary funding from the participating banks in accordance with the Rules of the scheme, and to receive and consider recommendations from the Banking Ombudsman for changes to the Terms of Reference and to recommend to the Council of the New Zealand Bankers' Association such amendments as the Commission thinks fit.

Clearly it is the strength and credibility of the Commission that guarantees the independence of the Banking Ombudsman and staff. Accountability of the Banking Ombudsman is to the Commission and, through the annual report, to the public.

In New Zealand there is also a unique relationship between the Parliamentary Ombudsman and those in the private sector: ${ }^{20}$ after a very long wait while the proposal languished in the limbo of legislative measures that have no potential to produce voter support, an amendment to the Ombudsmen Act was passed in December 1991 to protect the use of the name "ombudsman" which essentially gave the Chief Ombudsman control over who could use the name..$^{11}$

20 There is now also an Insurance and Savings Ombudsman, whose office commenced operations in 1995; further, as a result of the Inter-party Accord on Superannuation, the office of Retirement Commissioner was set up by the Retirement Ombudsman and other persons with similar complaint or dispute handling responsibilities (refer Section 6 (e) Retirement Income Act 1993) and also to review the kinds of. Whether that will proceed remains to be seen, but the report has been postponed from the end of 1994 until the first half of 1996.

21 Ombudsmen Act 1975, s28A (1) now provides; "No person, other than an Ombudsman appointed under this Act, may use the name "Ombudsman" in connection with any business, trade or occupation or the provision of any service, whether for payment or otherwise, or hold himself, herself or itself out to be an Ombudsman except pursuant to an Act or with the prior written consent of the Chief Ombudsman". 
The purpose behind seeking this amendment was twofold: first, to prevent the proliferation of "Ombudsmen" in such situations as internally appointed newspaper and college Ombudsmen who are little more than complaints advisers with no real independence and who damage the credibility of Ombudsmen properly so called; second, it presented an opportunity to set out criteria which would be used by the Chief Ombudsman when considering applications to use the name. ${ }^{22}$ Approval for use of the name "Banking Ombudsman" was granted on 2 April 1992. Between that time and February 1994, when the Chief Ombudsman approved the use of the term "Insurance and Savings Ombudsman", the approval requirement enabled the Chief Ombudsman to initiate further discussions with the insurance industry and consumer organisations which resulted in a single scheme to cover the insurance industry as a whole, rather than the separate Life Insurance and Fire and General Insurance Schemes first proposed. ${ }^{23}$

As for the Banking Ombudsman position in New Zealand, I had the interesting experience, having just completed my term as Parliamentary Ombudsman, of establishing the new office in accordance with its Terms of Reference and also the Criteria for approval.

The main objectives of a private sector Ombudsman scheme needed to be considered, as well as the requirements of the Terms of Reference. The first objective of a private sector Ombudsman scheme is to resolve disputes in such a way that the sheer inequality of power between a large, wealthy institution such as a bank, and its customer does not produce a situation where the customer feels unable to obtain redress. To this end the scheme provides an informal, speedy and cost-free alternative to the courts.

The second objective is securing a fair outcome. As is also the case with the Parliamentary Ombudsman, the scheme allows the dispute to be solved on a broader equitable basis than would be possible in the courts, since the Terms of Reference explicitly require the Banking Ombudsman, in making any recommendation or award, to do so by reference to what is, in his or her opinion, fair in all the circumstances. ${ }^{24}$ Any applicable rule of law is to be observed, and regard must be had to the general principles of good

22 The criteria were published in the Report of the Ombudsmen for the year ended 30 June 1992. It may be of some interest that the following year there was formed in the United Kingdom (and later joined by Eire) an Association of Ombudsmen in the Public and Private sector with criteria for membership very similar to the New Zealand criteria. In his capacity as President of the International Ombudsmen Institute, the New Zealand Chief Ombudsman Sir John Robertson addressed the inaugural Conference of the UK Ombudsman Association.

23 See Report of the Ombudsmen for the Year ended 30 June1992 page 37; Report of the Ombudsmen for the Year ended 30 June 1993 page 44; Report of the Ombudsmen for the year ended 30 June 1994 page 37; Report of the Chief Ombudsman Sir John Robertson on leaving Office. An application for approval by a local newspaper for an Editorial Ombudsman was declined as it did not meet No 4 of the criteria which is; "permission to use the name "Ombudsman" will not normally be granted for unique local or regional rules".

24 Terms of Reference Paragraph 16. 
banking practice and any relevant code of practice. ${ }^{25}$ The Banking Ombudsman is not bound by any previous decisions, an important point, since it removes the argument a bank might otherwise put up that it cannot make allowances for this particular customer as it would otherwise be stuck with a precedent.

The third objective is that the scheme not only functions as an alternative dispute resolution mechanism, but can go beyond the case-by-case approach of the courts and bring about changes to practice. In other words, it can work as a systematic audit. To this end the Banking Ombudsman is empowered to make recommendations to the Chairman of the Banking Ombudsman Commission from time to time in relation to the Terms of Reference or any relevant Codes of Practice which have a bearing on the discharge of his or her responsibilities. ${ }^{26}$

The key aim in relation to each objective is fairness. However good a legal system may be (and in a rapidly changing world where electronic banking is displacing older techniques such as cheques it is hard for the legislation to keep up with the needs of the commercial community), when an individual faces a powerful corporation across a courtroom, the imbalance in resources not only is likely to make the specific contest unfair, but fear of such a scenario may scare off many others who have a worthwhile case from bringing the issue to court. So fairness here demands a "level playing field". Part and parcel of that is building in protections into the rules that govern the relationship between the parties. This is where the Code of Banking Practice comes in, which sets out some customers' rights which in the past have not always been observed. ${ }^{27}$ Since the Code and the Scheme came into operation in 1992, the Consumer Guarantees Act 1993 from which banks, inter alia, unsuccessfully sought exemption, has come into effect and given a number of protections beyond those set out in the Code. ${ }^{28}$

The second aspect of fairness is in the process of dealing with disputes. This means allowing both sides to put their case, but it goes much further since the complainant is often unaware of information about the dispute that is necessary or could help his or her case. The Banking Ombudsman needs to look at a range of conduct, contracts and statements from each side. The Terms of Reference make it clear that in gathering such information the Banking Ombudsman is not bound by legal rules of evidence, though the parties are

25 Above n 24, Paragraph 16 (a) and (b).

26 Above n 24, Paragraph 33.

27 See Code of Banking Practice Clauses 2, 4, 2.6, 5.3.1, 10.5.1. The Code is at present in the process of being reviewed and submissions have been made on the proposed new Code.

28 The Consumer Guarantees Act 1993 came into force on 1 April 1994. In Section 2(1) the definition of "services" specifically includes in (c) a contract between a bank and a customer of the bank. 
protected by the reasons that must be given for any decision, which would need to refer to evidence on which those reasons are based.This is one area where the difference between a Parliamentary Ombudsman and an Ombudsman under a voluntary scheme is starkly obvious. The legislation gives the Parliamentary Ombudsman very wide statutory powers to obtain information from any person, and to put those with relevant information on oath, ${ }^{29}$ and provides any witnesses with protection and a defence even to what would otherwise be breach of secrecy provisions in other legislation. On the other hand the Terms of Reference, while they provide that the Banking Ombudsman may require the defendant bank to provide any information relating to that complaint which is, or is alleged to be, in its possession, ${ }^{30}$ and that the bank shall as soon as reasonably practicable disclose it to the Banking Ombudsman, represent simply a contractual undertaking to the Commission and are unenforceable by the Banking Ombudsman except through the influence of the Commission. The problem is even greater since the Terms of Reference themselves provide an exemption by which the Bank can certify that the disclosure of the information would place the bank in breach of its duty of confidentiality to a third party whose consent it had used its best endeavours to obtain. These assertions would be impossible for the Banking Ombudsman to verify, and the situation becomes even more difficult when one bank has attempted to claim the right to decide which of the information it holds is "information relating to the complaint". Since the Terms of Reference clearly state that it is for the Banking Ombudsman to decide whether or not a complaint falls within jurisdiction, such a claim to decide whether information "relates " to the claim would be able to undermine an investigation and must be untenable. It has to be emphasised that in most cases there is no problem with obtaining the full file, but there is a big difference between having full statutory powers, backed up by sanctions on the one hand, and relying on the respondent bank to honour its commitment on the other. Since the commencement of the Scheme in 1992 the Privacy Act 1993 has come into effect, and while at first this was perceived by some as another possible obstacle to satisfactory access to full information, it has now been accepted that the Banking Ombudsman can act as agent for the complainant to obtain all the information accessible under the Act, which would also permit enforcement via the Privacy Commissioner's Office. That new regime does not, of course assist where the complainant is a company since the Privacy Act only covers personal information about "an individual". 31

Above n 2, s 19.

Terms of Reference Paragraph 5.

31 Privacy Act 1993, Long Title and s2 definition of "individual" as a natural person, other than a deceased natural person. 
Another perceived difficulty in ensuring fairness of process is the "Test Case" provision. ${ }^{32}$

While this has never yet been used in New Zealand, it enables the bank, at any time before the Banking Ombudsman has made an Award, to give a notice in writing containing a statement, with reasons, that in the opinion of the bank the complaint involves or may involve an issue which may have important consequences for the business of the participating bank or banks generally or an important or novel point of law. The bank provides an undertaking that if, within six months of the Banking Ombudsman's receipt of the notice, either the complainant or the bank institutes proceedings in any Court in New Zealand in respect of the complaint, the bank will pay the complainant's costs and disbursements on a solicitor/client basis and make interim payments on account if it appears reasonable to the bank to do so. Providing the Banking Ombudsman concurs with the bank's statement, the investigation must then be discontinued.

In spite of criticism that has been aimed at this provision (and similar ones in the UK and Australia), since the Banking Ombudsman's concurrence is required it is doubtful that this provision could be abused, particularly as the Terms of Reference in any case provide that if, at any time, it appears to the Banking Ombudsman that the complaint would be more appropriately dealt with by a court, the Banking Ombudsman can relinquish jurisdiction. ${ }^{33}$

So, how does "fairness" under a voluntary private sector Scheme compare with "fairness" in the public sector?

In both cases what Ombudsmen do is, like Chancellors in the Middle Ages, to supplement and ameliorate the law applied by the courts and to provide alternative procedures not available in the courts. The courts of today, on the basis of much new legislation that has enhanced the civil and consumer rights of the public, can do much more than formerly to ensure fairness in administration and commerce, and the standards set by the courts are carefully noted by Ombudsmen. At the end of the day, however, courts are setting

32 Terms of Reference Paragraph 23.

33 The drafting is curious. Under the heading "Limits on the Banking Ombudsman's Powers" Paragraph 18 provides:

The Banking Ombudsman shall have power to consider a complaint made to him or her except:

(d) if at any time it appears to the banking Ombudsman that it is more appropriate that the complaint be dealt with by a court, under another independent or statutory complaints or conciliation procedure or under an arbitration procedure;

(e) if any Participating Bank named in the complaint gives the Banking Ombudsman a notice of the kind described in paragraph 23.

What is in fact a discretion not to investigate or to discontinue an investigation not unlike the provision in Section 17(1)(a) of the Ombudsman Act 1975 is here made a jurisdictional limitation. 
precedents about liability and that is why Ombudsmen, because they have a freer hand under their legislation or terms of reference, can more easily tailor a fair remedy to the specific case.

There are still important differences between public sector and private sector Ombudsman jurisdiction: whereas in the public sector any matter of administration involving listed organisations can be investigated on complaint or on the Ombudsman's own motion, in the private sector only those matters specified in the Terms of Reference can be looked at and there is no "own motion" jurisdiction. So, in the case of the Banking Ombudsman Scheme there are a number of limitations; the claim cannot be above $\$ 100,000$, the act or omission complained of must have occurred after 1 January 1992 (or six months earlier, and not have been reasonably discoverable until after 1 January 1992), and there is no jurisdiction to consider a complaint that relates to a commercial judgment in decisions about lending or security, or interest rate policies or a practice or policy of a bank which does not itself give rise to a breach of any obligation or duty owed by the bank to the complainant. Within those limitations, the Banking Ombudsman can investigate, try to get a resolution, and failing that may make a recommendation as to how the matter should be settled. If the complainant accepts the recommendation but the bank does not, a binding award can be made against the bank.

The binding award is an important difference; the outcome of a Parliamentary Ombudsman investigation is a recommendation and, if the respondent organisation does not accept it, a report to the Prime Minister and thence to Parliament. That last step has only had to be resorted to in extremely rare circumstances. In the case of a complaint relating to a local authority, where a recommendation is not accepted,the Ombudsman may send a copy of the report to the Mayor or Chairman of the organisation and may require it to publish, at its own expense, a summary of the report.

Fairness is a two way process, the Ombudsman must be fair to both the complainant and the defendant in process, on the merits, and in the outcome. Fairness is a constantly developing concept and as the public's concerns about commercial or civic powerlessness and downstream effects of information technology are reflected in new legislation such as the New Zealand Bill of Rights Act 1990, the Human Rights Act 1993, the Privacy Act 1993 and the Consumer Guarantees Act 1993 or in judicial decisions, the relevant Ombudsman can revise upwards the standard of fairness to be applied. However Ombudsmen have to remember that there is no such thing as a free lunch, and in the private sector measures that may be fair to one person may increase the costs of a service to such an extent that it will disadvantage and so be potentially unfair to many others. So it is important to keep some balance in what is decided in respect of an individual complainant; it would be counterproductive if doing what seemed fair for one put unreasonable burdens on the many. Perhaps one main thing that is lacking in the present Terms of Reference of the Banking 
Ombudsman Scheme is a requirement, when considering what is good practice, to consult with consumer representatives as well as with the banks. When the time comes to evaluate how the Scheme has operated since its inception that change to the Terms of Reference may be worth considering.

\section{L'experience neo-zélandaise de l'application des règles relatives à l'institution de l'Ombudsman dans le secteur privé}

Les Néo Zélandais sont fiers des nombreuses avancées sociales que l'on doit à leur système légal. Il suffira de faire référence au droit de vote octroyé au femmes des 1893, et quelques dispositions uniques en leur genre dans le domaine du droit de la famille. Il faut également mentionner l'Ombudsman Act de 1962 complété par l'Ombudsmen Act de 1975, qui tous deux ont façonné de nouveaux rapports entre le citoyen et l'administration Néo Zélandaise. Inspiré du système suédois, l'idée principale qui soutend cette institution repose d'une part sur la prise de conscience du déséquilibre des forces qui existent entre l'administration et les administrés et d'autre part sur la nécessité qu'il y a pour ces derniers, de pouvoir compter sur les services d'une personne impartiale dans le cadre de litiges qui pourraient naître entre eux.

La section 22 du Ombudsmen Act de 1975 pose comme principe que la décision administrative soumise au contrôle de l'Ombudsman doit "apparaître comme contraire à la loi". Sans empiéter sur le domaine réservé des tribunaux, les décisions de l'Ombudsman se présentent comme des avis sur la légalité de telle ou telle decision administrative. Au delà du premier critère de l'illégalité apparente, les agissements de l'administration seront susceptibles d'etre déférés à la censure de l'Ombudsman chaque fois qu'il est déraisonnable (c'est à dire ce qu'un citoyen ordinaire le considère comme inacceptable), injuste ou discriminatoire au regard des textes en vigueur. Sur ce fondement, le contrôle de l'Ombudsman a pu etre étendu aux textes qui sont les supports de l'acte administratif incriminé. De la mémé manière chaque fois que le comportement de l'administration repose sur une interprétation de la loi totalement ou partiellement fausse, l'Ombudsman se verra reconnaitre compétence. Un dernier fondement est proposé par la section 22 du Ombudsmen Act de 1975, et c'est sans aucun doute le plus vague, puisqu'il autorise une intervention lorsque l'action de l'administration est "erronée". Enfin, grâce a l'intervention des tribunaux, alliée à quelques dispositions législatives spécifiques, le contrôle de la motivation des actes administratifs entre aujourd'hui dans le champ de compétence de l'Ombudsman.

Le succès de l'institution a été tel qu'il n'est guère surprenant qu'elle ait été étendue au secteur privé. L'objectif poursuivi était à l'instar des législations précédentes de promouvoir un équilibre des forces entre les consommateurs et les grands groupes 
industriels et financiers. Sans réellement s'inspirer du modèle anglais, mis en place en 1986, le secteur bancaire fut le premier en Nouvelle Zzélande à connaître en 1992 le recours à l'Ombudsman.

Un organisme a été créé entre les institutions bancaires et l'Ombudsman bancaire, l'Ombudsman Banking Commission présidée par un haut magistrat de l'ordre judiciaire et composé de deux représentants des associations de consommateurs et de deux représentants des organismes financiers. Il appartient à cette commission de nommer l'Ombudsman, tout en remplissant une fonction de conseil tant auprès du gouvernement que des institutions bancaires.

La première tache de l'Ombudsman dans le secteur privé est de rendre une decision équitable. Pour ce faire il est affranchi des traditionnelles règles en matiere de preuves de telle sorte que sa marge de manoeuvre apparait bien plus grande que n'importe quel tribunal et qu'il agit comme un véritable audit de l'ensemble de l'institution bancaire. La législation donne à l' Ombudsman des pouvoirs extrêmement étendus tant dans la recherche des preuves et éléments d'informations matérielles que pour l'audition de témoins.

Sur le plan pratique cette recherche se heurte néanmoins au secret bancaire et à la possibilité pour les banques de mettre un terme à la procédure en indemnisant le consommateur plaignant, privant ainsi l'Ombudsman de la possibilité de mener à terme ses investigations. Il reste toutefois que la pratique du recours à l'Ombudsman dans le secteur privé offre au consommateur une possibilité de règlement extra judiciaire des litiges qui l'oppose au secteur privé à commencer par le secteur bancaire. 